\title{
LAUR-7 $4-740$
}

This repurt was prepared as an account of work This report was prepared States Government. Neither sponsored by nor the United States Atomic Energy their employees, nor any of Commission, hor any of thactors, or their employees, their contractors, subcontractors, or thed, or assumes any makes any warranty, express or for the accuracy, comlegal liability or responsibilty for the accuracy, coms, pleteness or usefulness of any information, that its use product or process disclosed, or represents

ROCK MELTING SUBTERRENES--THEIR ROLE

IN FUTURE EXCAVATION TECHNOLOGY

by John C. Rowley, Robert J. Hanold

Charles A. Bankston and Joseph W. Neudecker

Staff Members, Energy Division, University of California

Los Alamos Scientific Laboratory

Los Alamos, N. Mex. 87544

ABSTRACT

The basic concepts and processes of soil and rock melting as applied to excavation technology are reviewed. The electrically heated, small diameter prototype penetrator development sequence is presented. Emphasis is placed on the different methods of handling the fluid rock and soil melts and their significance in providing new solutions in hole support and debris handling problems. The refractory materials requirements, penetrator life and electrical heater technology are presented.

Consolidating penetrators, which form stable glass-lined holes in low density rocks and soils, require no debris removal and will find applications in horizontal holes for utilities, cables, and pipeline installations. Extruding penetrators are being developed to make holes in dense, hard rocks. Melt is conditioned into a variety of debris forms, i.e., glass rods, pellets or rock wool, selected to match appropriate debris handling systems. Unique use in arilling into very hot rock or magma for geothermal exploration or production wells is projected. Some of the results of laboratory and field tests of these devices are compared with theoretically derived operating performance.

Coring-consolidating penetrators for geological sampling in alluvium are projected to larger diameter self-propelled and guided coring devices for prospecting along proposed tunnel alignments. Application to the melting of annular shafts for pipeline support piles in difficult conditions such as permafrost has been scoped. Conceptual design studies of large diameter tunneling equipment have indicated the system contributions and economic aspects of rock melting relative to material comminution, wall and roof support and materials handling. 


\section{DISCLAIMER}

This report was prepared as an account of work sponsored by an agency of the United States Government. Neither the United States Government nor any agency Thereof, nor any of their employees, makes any warranty, express or implied, or assumes any legal liability or responsibility for the accuracy, completeness, or usefulness of any information, apparatus, product, or process disclosed, or represents that its use would not infringe privately owned rights. Reference herein to any specific commercial product, process, or service by trade name, trademark, manufacturer, or otherwise does not necessarily constitute or imply its endorsement, recommendation, or favoring by the United States Government or any agency thereof. The views and opinions of authors expressed herein do not necessarily state or reflect those of the United States Government or any agency thereof. 


\section{DISCLAIMER}

Portions of this document may be illegible in electronic image products. Images are produced from the best available original document. 


\section{INTRODUCTION}

A wide variety of physical processes for rock fragmentation and comminution have been studied and proposed as bases for new drilling and tunneling systems; for example, refer to the reviews of Maurer(1) and Olson and Atchison. (2) Modes of thermally fracturing rock and of fusing rock or soil, as well as some of the research efforts in this general area have been reviewed by Carstens. (3) He indicates the basic advantages of the thermal approaches, noting specifically that thermal processes can deliver energy to a working face with greater intensity than mechanical systems, are subjected to less wear, and can be relatively insensitive to wide variations in strength and hardness of the formation.

This paper reviews the results of a research and development project that is directed toward perfecting the rock- and soil-melting process into practical excavation tools. The work is a result of early studies, (4-5) and the initial experimental efforts which selected the approach of developing electrically heated, refractorymetal penetrators that are mechanically thrust into the working face and transfer heat primarily by conduction and radiation. This selection was based upon the controlled formation of the "debris" in the form of a fluid. The techniques of handling this melt form the basis for new excavation systems that can simultaneously: (1) form the required shape of the bore hole or tunnel, (2) support the excavation by chilling the melt into a glass-like lining on the walls, and (3) make the "muck" or cuttings into forms that can be selected to match efficient materials handling equipment suitable for the particular project. Major objectives of the program have been to explore the variety of available melting modes, to perfect the possible melt-handling techniques, to provide analytical models of system operating performance, to extend system performance relative to penetration rate and operating life, and to demonstrate the importance and potential of a total system approach to new solutions in excavation technology. These rock melting systems have been termed "subterrenes".

\section{ROCK MELTING PENETRATOR FUNDAMENTALS}

The known melting temperatures of refractory metals, for structural components, graphites for electrical heaters and thermal insulators, and a variety of nitrides and oxides for electrical insulators show(6) that materials with sufficient temperature margin relative to rock and soil melting temperature ranges are available for construction of penetrators. In practice, structural components fabricated from molybdenum and tungsten of the required configurations can be designed to have practical creep-rupture lives in excess of $1000 \mathrm{hr}$. Material temperatures in the range of 1300 to 1900 Kelvin $\left(1880\right.$ to $2960^{\circ} \mathrm{F}$ ) have been found to be sufficient to melt most rocks and soils of interest. 
Figure 1 illustrates schematically the penetrator system. The physics of melting by the penetrator yields the following relation between melting energy $E_{m}$ and penetration rate $v$,

$$
v \cdot \rho \cdot A_{m}\left[C_{p}\left(T_{m}-T_{o}\right)+\Delta H_{L}\right]=\dot{E}_{m}
$$

Equation (1) can be rearranged into the form

$$
V=K\left(\frac{\dot{E}_{H}}{A_{m}}\right) \frac{1}{(1+\eta)}
$$

which is the basic operating relation, where:

$$
\begin{aligned}
& \rho=\text { density of rock or soil } \\
& C_{p}=\text { specific heat } \\
& T_{m}=\text { melting temperature } \\
& T_{0}=\text { ambient temperature } \\
& \dot{\Delta H}_{L}=\text { effective heat of fusion } \\
& A_{m}=\text { melted cross-sectional area } \\
& \eta \quad=\text { efficiency factor to account for heat losses to stem } \\
& \dot{E}_{H}=\text { heater power } \\
& { }_{K}=\text { a factor containing the rock or soil properties. }
\end{aligned}
$$

Equation (2) shows that the penetration rate is predicted by a relation which is essentially directly proportional to a heater power, i.e., an increase in rate is achieved by increasing heater power。 Also the equation indicates that maximum rate is limited by the heat flux $\left(\dot{E}_{\mathrm{H}} / A_{\mathrm{m}}\right)$ that can be transferred from the heater, through the internal structure of the penetrator, through the melt layer and to the melt layer-to-rock interface. This limit is determined by the maximum practical temperature levels at which the internal components of the penetrator can operate $(7,8)$, which in turn are related to operating life of the device. These limits can be established by thermal analysis (9) and laboratory experiments and component tests.

Figure 1 also illustrates the formation and growth of the rockmelt layer around the penetrator body. This layer serves to partially protect the refractory metal body from abrasion. There is another life limiting factor which results from the interaction of the melt with the high temperature refractory metal. This results in a slow removal of material from the surface by interaction with the fluid melt, however a stable complex of solid oxides and silicides has been shown to significantly retard this effect. Service 
life evaluations in both laboratory and field tests conducted thus far have indicated the potential for long operating lifetimes.

The sketch in Figure 1 also shows two other basic features of penetrator systems under development. The need for a stem coolant system, usually provided by a water or gas (air) flow. This coolant performs the primary function of cooling the non-refractory stem (fabricated from steel pipe) and the most important secondary task of providing a controlled chilling of the melt to a solid state. For the configuration sketched in Fig. 1, as a glass-like lining on the hole depicted in Fig. 2. This melt-conditioning function of the coolant is essential to the operation of the penetrator systems. A sharp temperature transition between the hot refractory melting body and the melt forming-chilling structure is essential to prevent melt sticking and this transmission is provided by a heat blocking insulator (usually formed from pyrolytic graphite). Proper thermal design of the glass forming section has been accomplished by a combination of thermal and heat transfer analysis and experimental work. (10)

The detailed theoretical prediction of rock melting penetrator performance and optimization studies(11) require the knowledge of the thermal and physical properties of rock, soils and melts. Most of these data are available $(12,13)$ in sufficient quantity and quality to predict the heat loss from penetrators $(14,15)$ and to select geometries to minimize heat losses. The basic rock melting relationships given in equations (1) and (2) have been verified(16) by instrumented laboratory experiments and field test data. The relative insensitivity of performance to a wide range of rocks and soils has also been established by these tests. This work has confirmed the general



Fig. 1--Schematic section of electrically heated, consolidating penetrator.
Fig. 2--Typical glass lined hole melted in low density tuff by consolidating penetrator. 
predictability of the system and has provided a firm basis for calculating the performance of conceptual designs of different excavation equipment configurations and has established the ability to scale up to larger sizes.

PENEIRATOR MELTING MODES AND MELT HANDLING

The flexiblity in design and wide range of projected application of subterrene systems is based upon the variety of available melting modes and melt handling techniques. Figure 3 illustrates four of these basic schemes. The simplest configuration, Fig. 3a, termed the consolidation mode, shows a full-face melting penetrator. The unit advances in low density rock or loose soils by melting the material in the hole and sufficient additional material to form a higher density glass-like lining. Thus, a stable hole is formed with no debris removal requirement. Figure 4 is a section view of a gas cooled penetrator designed(17) on the consolidation principle and Fig. 5 is a photograph of one of these devices after extensive testing. The thickness of the glass lining for a circular cross section hole is given by the equation

$$
\frac{r_{g}}{r_{h}}=\frac{1}{\sqrt{1-\rho_{R} / \rho_{L}}} .
$$

where $r_{g}=$ outer radius of glass lining

$$
\begin{aligned}
& r_{h}=\text { radius of hole } \\
& \rho_{R}=\text { density of the parent rock or soll } \\
& \rho_{L}=\text { density of the lining }\left(\rho_{L}>\rho_{R}\right) \text {. }
\end{aligned}
$$

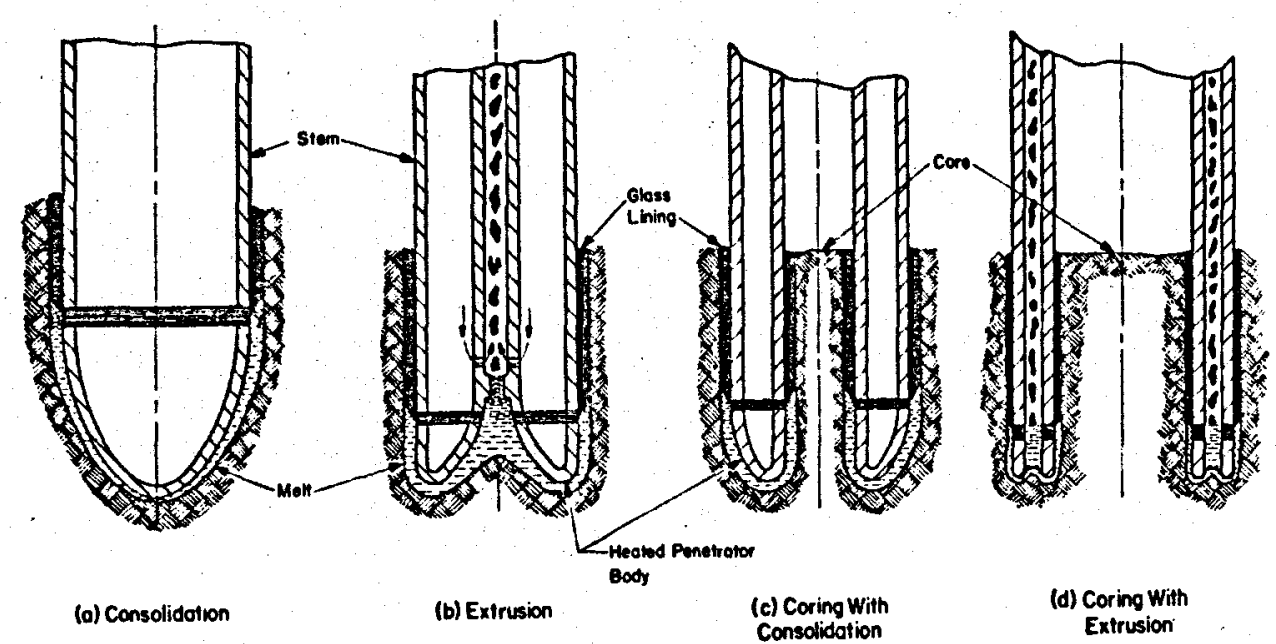

Fig. 3--Section sketch of various penetrator melting modes and melt handling techniques. 
Figure 6 is a photograph of the exterior of a glass lined hole formed in a sample of loose gravel by a consolidating penetrator.

The second mode of melting and melt handling is shown in Fig. 3b. This configuration is used in dense and hard rocks where consolidation is not possible. The melt is extruded through a melt flow hole (or holes) in the penetrator body. The melt then exits through a chill nozzle, where the stem coolant chills the melt into a solid debris. Figure 7 shows a section view of this design(18) with a single extruding channel. A variety of debris types or cuttings can be formed with extruding penetrators. Figures 8 and 9 show typical holes and debris. The hole formed in a low density rock type (tuff) and glass rods removed (Fig. 9) indicates the universal nature of these extruding penetrators in their ability to penetrate lower density materials in addition to denser formations.

Figures $3 c$ and $3 d$ illustrate two additional modes of melting. Figure $3 \mathrm{c}$ is a consolidating-coring penetrator designed to take glass cased cores in loose soils and gravels. Figures 10 through 12 indicate the details of the design, (19) a photograph of the penetor body and a section of core retrieved during initial tests of the unit. The coring-extruding combination shown in Fig. 3d is the melting mode and melt handling concept to be applied to coring in dense rock.

The successful design, fabrication and testing of the above variety of melting penetrators has formed the technological base for a wide range of excavation applications. (20) The electric heaters required for the various devices have also been developed and technical approaches to provide advanced heater subsystems established.(21) Various types of special drilling and tunneling tools can now be designed and developed based upon combinations of the basic melting configurations and melt handling techniques established in the development.

\section{EXPERIMENTAL AND THEORETICAL RESULTS AND FIELD TESTS}

The theoretical prediction models for the subterrene devices have been formulated in computer programs which yield detailed thermal and heat transfer representations, (22) structural analysis for creep and thermal stress evaluations(23) and operating performance predictions. (11) These analytical results have been verified by data obtained in laboratory experiments as illustrated in Fig. 13.

Simple modularized, portable field test and demonstration units $(24,25)$ have been designed and used to provide field test experience. Field tests of both vertical and horizontal holes(26) have confirmed operating parameter relationships. The field unit designed for use with a $50 \mathrm{~mm}$ ( $2 \mathrm{inch}$ ) diameter consolidating penetrator has been 
utilized(27) to melt drainage holes in the floors of Indian ruins in collaboration with the National Park Service.

\section{EXCAVATION SYSTEMS}

Based upon the development efforts completed thus far a number of excavation systems have been projected. The results of melting horizontal holes in field tests (Fig. 14) have indicated that a system for melting small diameter, horizontal holes with controlled deviations from straightness, Fig. 15, can be developed. (28) This type of equipment will find many uses in forming glass-lined holes for the installation of utilities, cables and pipelines in construction projects. Significant advantages for installations in loose gravel's and difficult soils are foreseen. Development of position sensor and guidance subsystems for hole straightness and programmed deviation control are possible with this system.

Increasing the diameter of the equipment and providing for coring capability, the design of equipment for accomplishing geologic surveys of the alignment of a proposed tunnel route is possible. (29) This device can include an in-hole packer-thruster unit, position sensors, automatic feed back for path control, and formation logging instrumentation. Application as a mini-tunneler is also projected. A sketch of the equipment is shown in Fig. 16.

The scale up to larger diameters to provide conceptual designs of tunneling systems $(30)$ is also possible due to the predictability of the melting process. Power requirements, subsystem specifications and costs (31) can be readily projected. These systems analyses and conceptual design studies have shown that rock-melting tunnelers for use in soft ground, Fig. 17, may show the largest advantages as compared to presently used equipment. This is primarily a result of the possibility of melting the periphery and formation of a glass lining for temporary support in difficult ground and accomplishing this immediately behind the working face. A mock up of such a formed-inplace tunnel support system is shown in Fig. 18. This particular demonstration of tunnel lining was performed by successively melting parallel, horizontal holes with a $50 \mathrm{~mm}$ ( 2 inch) diameter consolidating penetrator in such a manner that the successive glass tubes overlapped and fused together. A stable and continuous lining was formed and the loose alluvium fill of the embankment was easily excavated from within the lining. The extension to the placement of a complete set of specially shaped penetrators located continuously around the pexiphery of an existing soft ground tunreling machine is easily visualized.

Current penetrator design and development efforts are concentrated on a prototype penetrator (Fig. 19) suitable for geothermal well drilling. This $85 \mathrm{~mm}$ (3-1/2 inch) diameter extruding system is undergoing field trials in basalt using a drill rig, Fig. 20, which can handle $\sim 300 \mathrm{~m}$ (1000 ft) of stem. 


\section{DISCUSSION AND CONCLUSIONS}

The development of rock melting penetrators has reached the stage where the preliminary design of specific excavation equipment can be considered. The power and coolant requirements and handling equipment çan be defined. The operating parameters and special penetrator configurations can be predicted and optimized using available analytical techniques. It is felt that the first comercial equipment developed for practical use will be applied to the formation of small diameter, horizontal, glass lined holes in difficult ground for utility, cable and pipeline installations.

\section{ACKNOWLEDGEMENTS}

The authors wish to acknowledge a grant from the National Science Foundation, Research Applied to National Needs, and the encouragement and guidance received from $D r$. William $W$. Hakala of that agency. The work was performed under the auspices of the U. S. Atomic Energy Commission at the Los Alamos Scientific Laboratory.

\section{REFERENCES}

(1) Maurer, W. C. , Novel Drilling Techniques, London, Pergamon Press Ltd., 1968,

(2) Olson, J. J., and Atchison, T. C., "Research and Development--Key to Advances for Rapid Excavation in Hard Rock," Proceedings, ASCE-AIME, First North American Rapid Excavation and Tunneling Conference, Vol. 2, pp. 1393-1441, Chiçago, 1972.

(3) Carstens, J. P., "Thermal Fracture of Rock--A Review of Experimental Results," Proceedings, ASCE-AIME, First North American Rapid Excavation and Tunneling Conference, Vol. 2, pp. 1363-1392, Chicago, 1972.

(4) Armstrong, D. E., et al., "Rock Melting as a Drilling Technique," Los Alamos Scientific Laboratory Report No. LA-3243,* 1965.

(5) Smith, M. C., ed., "A Preliminary Study of the Nuclear Subterrene," Los Alamos Scientific Laboratory Report No. LA-4545,* 1971.

(6) Krupka, M. C.. "Phenomena Associated with the Process of Rock Melting, Application to the Subterrene System," Los Alamos Scientific Laboratory Report No. LA-5208-MS,* 1973.

(7) Krupka, M. C., "Thermodynamic Stability Considerations in the Mo-BN-C System, Application to Prototype Subterrene Penetrators," Los Alamos Scientific Laboratory Report No. LA-4959-MS,* 1972. 
(8) Stark, W. A., and Krupka, M. C., "Carbon Receptor Reactions in Subterrene Penetrators," Los Alamos Scientific Laboratory Report No. IA-5423-MS, * 1973.

(9) Gido, R. G., "Internal Temperature Distribution of a Subterrene Rock-Melting Penetrator," Los Alamos Scientific Laboratory Report No. LA-5135-MS, * 1973.

(10) Stanton, A. E., "Heat Transfer and Thermal Treatment Processes in Subterrene-Produced Glass Hole Linings," Los Alamos Scientific Laboratory Report No. LA-5502-MS,* 1974.

(11) McFarland, R. D., "Numerical Solution of Melt Flow and Thermal Energy Transfer for the Lithothermodynamics of a RockMelting Penetrator, Los Alamos Scientific Laboratory Report No. IA-5608-MS,* 1974 .

(12) Krupka, M. C., "Selected Physicochemical Properties of Basaltic Rocks, Liquids, and Glasses," Los Alamos Scientific Laboratory Report No. IA-5540-MS, *

(13) Clark, G. B., et al., "Rock Properties Related to Rapid Excavation," University of Missouri, Rolla, Report No. PB-184767,* 1969.

(14) Murphy, H. D., and Gido, R. G., "Heat Loss Calculations for Small Diameter Subterrene Penetrators," Los Alamos Scientific Laboratory Report No. LA-5207-MS, * 1973.

(15) Cort, G. E., "Rock Heat-Loss Shape Factors for subterrene Penetrators," Los Alamos Scientific Laboratory Report No. LA-5435-MS,* 1973.

(16) Gido, R. G., "Subterrene Penetration Rate: Melting Power Relationship," Los Alamos Scientific Laboratory Report No. LA-5204-MS, * 1973.

(17) Neudecker, J. W., "Design Description of MeltingConsolidating Prototype Subterrene Penetrators," Los Alamos Scientific Laboratory Report No. LA-5212-MS,* 1973.

(18) Neudecker, J. W., et al., "Design and Development of Prototype Universal Extruding Subterrene Penetrators," Los Alamos Scientific Laboratory Report No. LA-5205-MS,* 1973.

(19) Murphy, H. D., "Development of Coring Consolidating Subterrene Penetrators," Los Alamos Scientific Laboratory, report in preparation. 
(20) Sims, D. L., "Identification of Potential Applications for Rock-Melting Subterrenes," Los Alamos Scientific Laboratory Report No. LA-5206-MS , * 1973.

(21) Armstrong, P. E., "Subterrene Electrical Heater Design and Morphology," Los Alamos Scientific Laboratory Report No. LA-5211-MS,* 1974.

(22) Lawton, R. G., "The AYER Heat Conduction Computer Program," Los Alamos Scientific Laboratory Report No. LA-5613-MS, * to be published.

(23) Lawton, R. G., "PLACID: A General Finite-Element Computer Program for Stress Analysis of Plane and Axisymmetric Solids," Los Alamos Scientific Laboratory Report - to be published.

(24) Williams, R. E., "Development of a Modularized Mobile RockMelting Subterrene Demonstration Unit," Los Alamos Scientific Laboratory Report No. LA-5209-MS, * 1973.

(25) Griggs, J. E., "Development of a Mobile Rock-Melting Subterrene Field Unit for Universal Extruding Penetrators," Los Alamos Scientific Laboratory Report No. LA-5573-MS, * 1974.

(26) Gido, R. G., "Description of Field Tests for Rock Melting Penetration," Los Alamos Scientific Laboratory Report No. LA-5213-MS,* 1973.

(27) Williams, R. E., and Griggs, J. E., "Use of the RockMelting Subterrene for the Formation of Drainage Holes in Archaeological Sites," Los Alamos Scientific Laboratory Report No. LA-5370-MS, * 1973.

(28) Sims, D. L., "A Versatile Rock-Melting System for the Formation of Small-Diameter Horizontal Glass-Lined Holes," Ios Alamos Scientific Laboratory Report No. LA-5422-MS,* 1973.

(29) Neudecker, J. W., "Conceptual Design of a Coring Subterrene Geoprospector," Los Alamos Scientific Laboratory Report No. IA-5517-MS, * 1974.

(30) Hanold, R. J., "Large Subterrene Rock-Melting Tunnel Excavation Systems," Los Alamos Scientific Laboratory Report No. IA-5210-MS, * 1973.

(31) Altseimer, J. H., "Systems and Cost Analysis for a Nuclear Subterrene Tunneling Machine," Los Alamos Scientific Laboratory Report No. LA-5354-MS,* 1973.

*These reports can be obtained from the U. S. National Technical Information Service, Dept. of Commerce, 5285 Port Royal Road, Springfield, VA 22151 

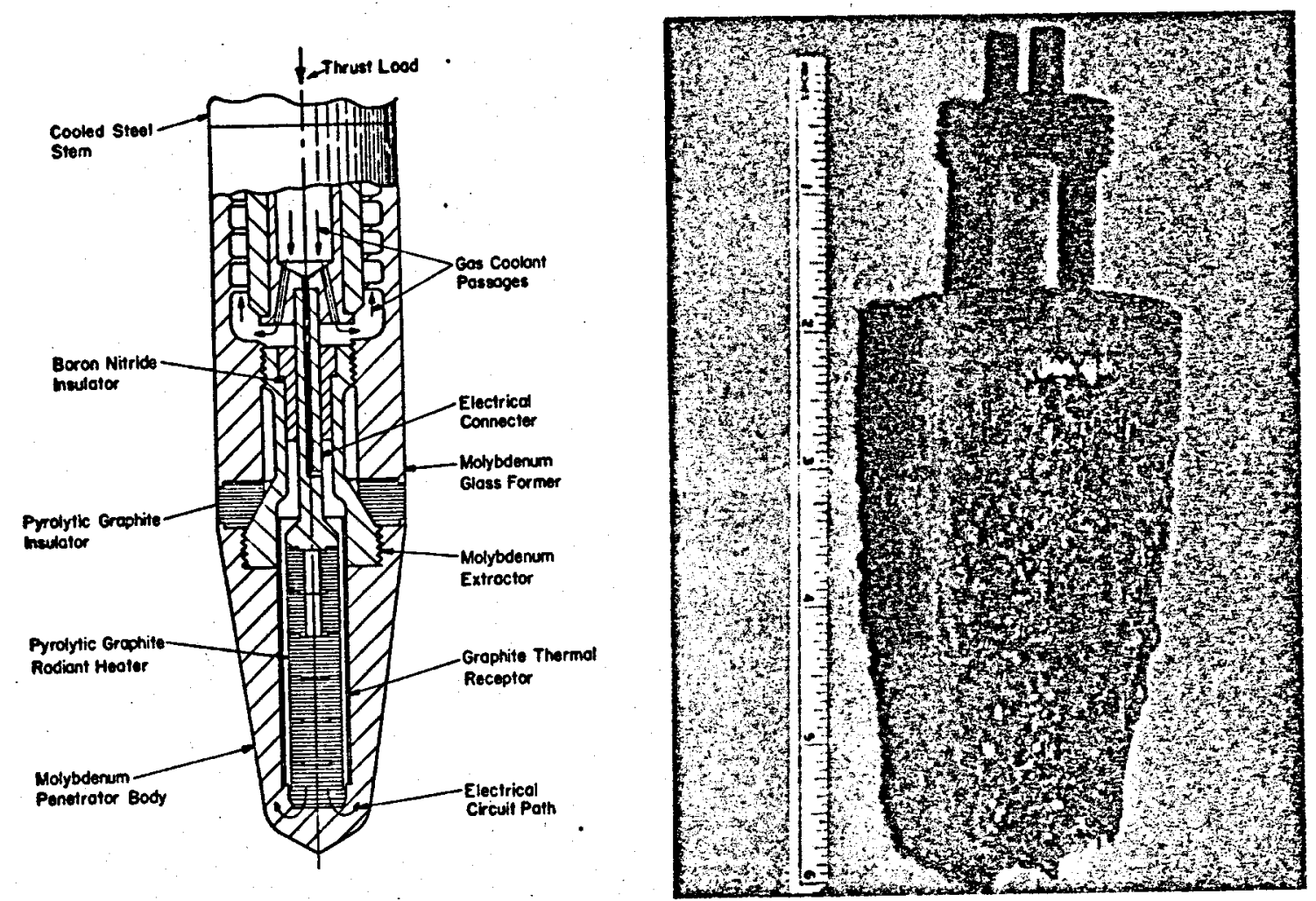

Fig.4--Cross section of consolidating penetrator design.

Fig. 5--Photograph of $50 \mathrm{~mm}$ (2 inch) diameter consolidator after test.



Fig. 6--Photograph of exterior of glass lined hole formed in loose gravel with consolidating penetrator. 


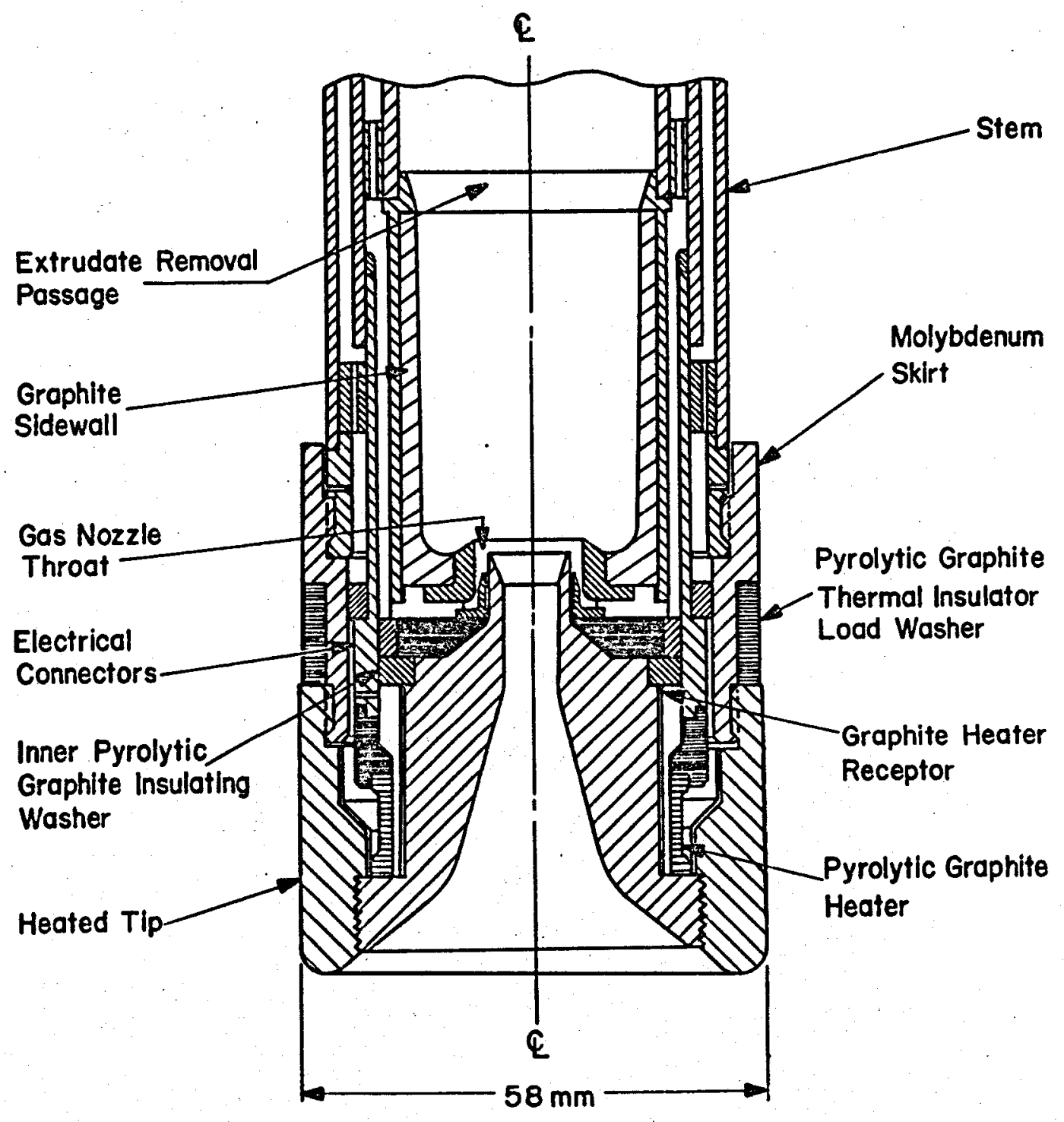

Fig. 7--Cross section of single flow channel, extruding penetrator design. 


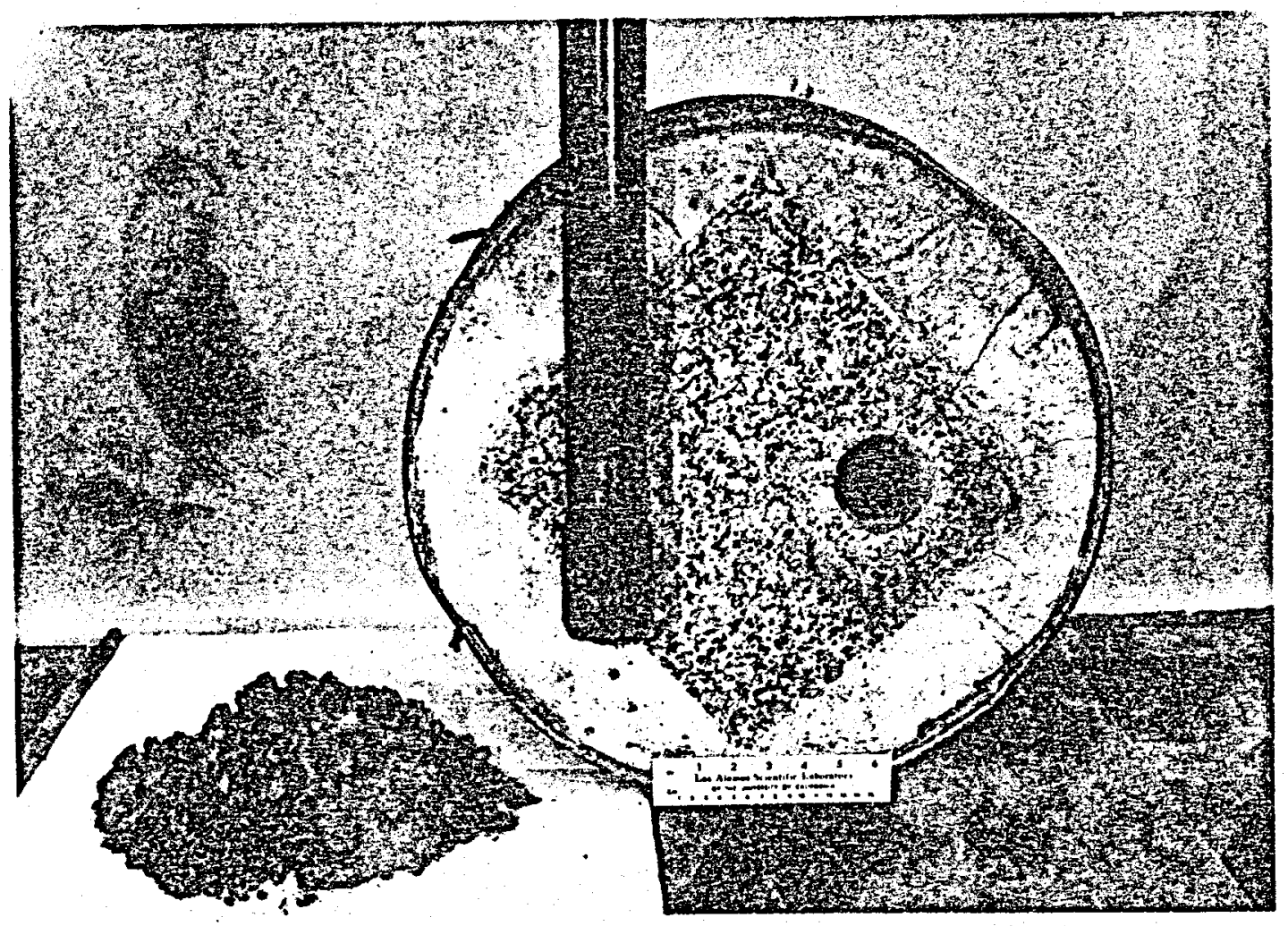

Fig. 8--Hole melted in granite sample with extruding penetrator, debris in the form of glass pellets and rock wool.

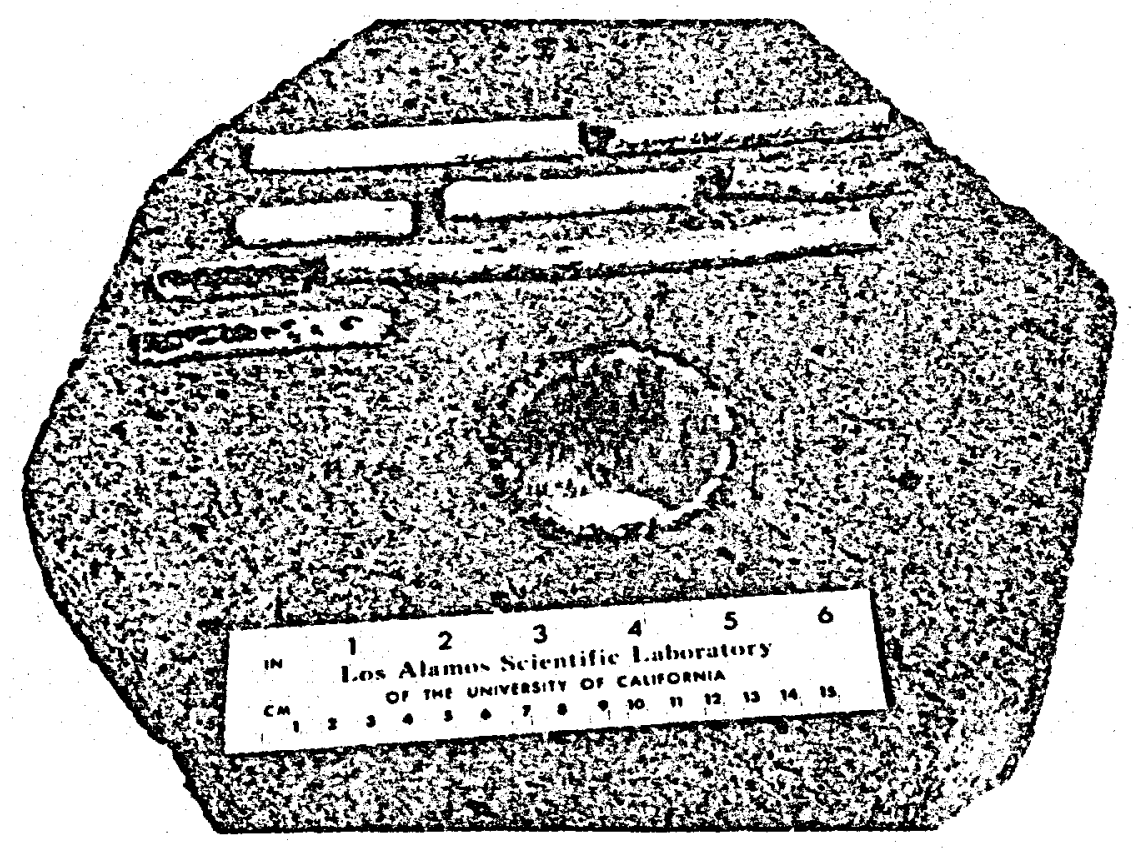

Fig. 9--Hole melted in low density tuff with extruding penetrator. Note thin glass lining and glassrod debris form. 


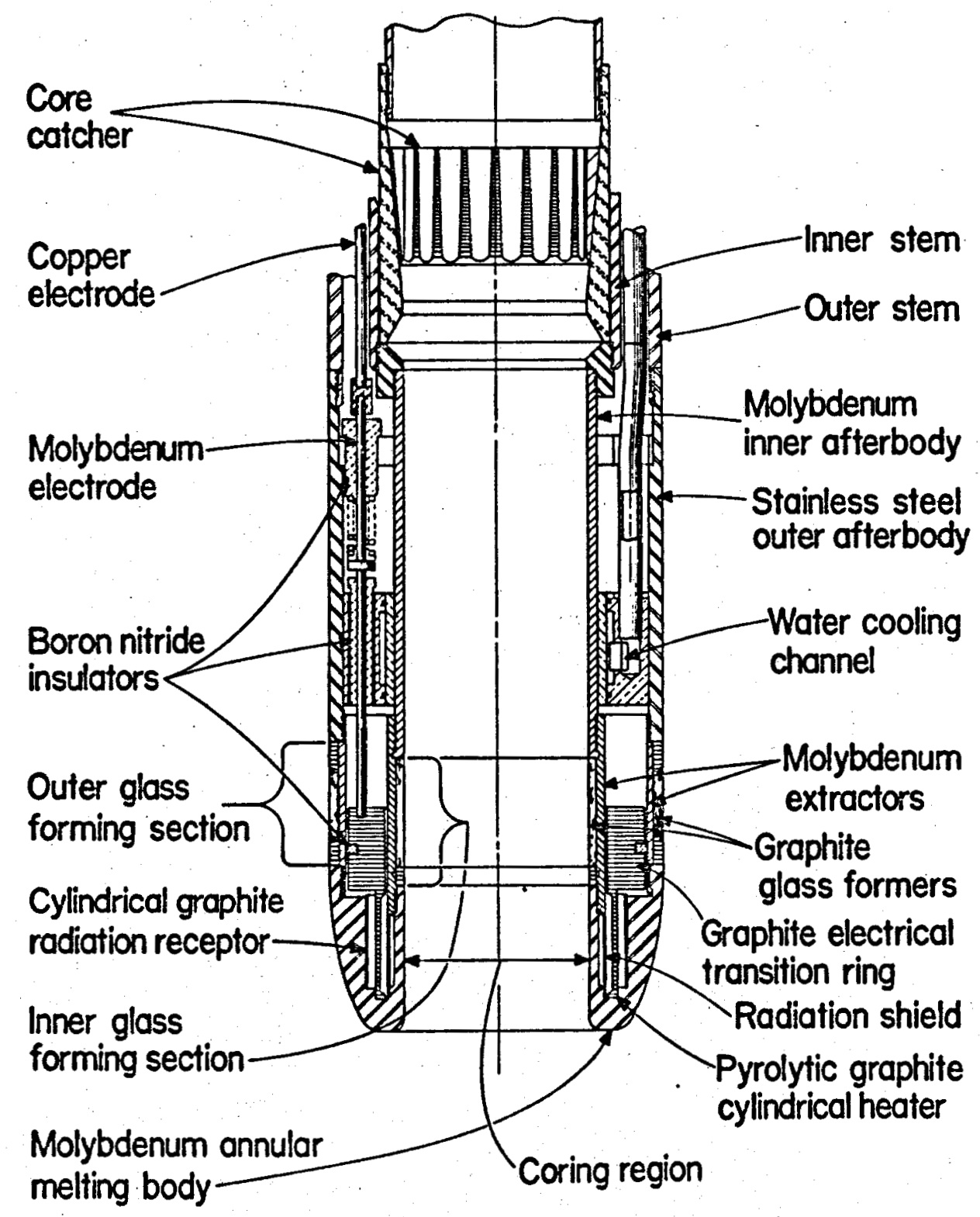

Fig. 10--Design concept of consolidatingcoring penetrator. 


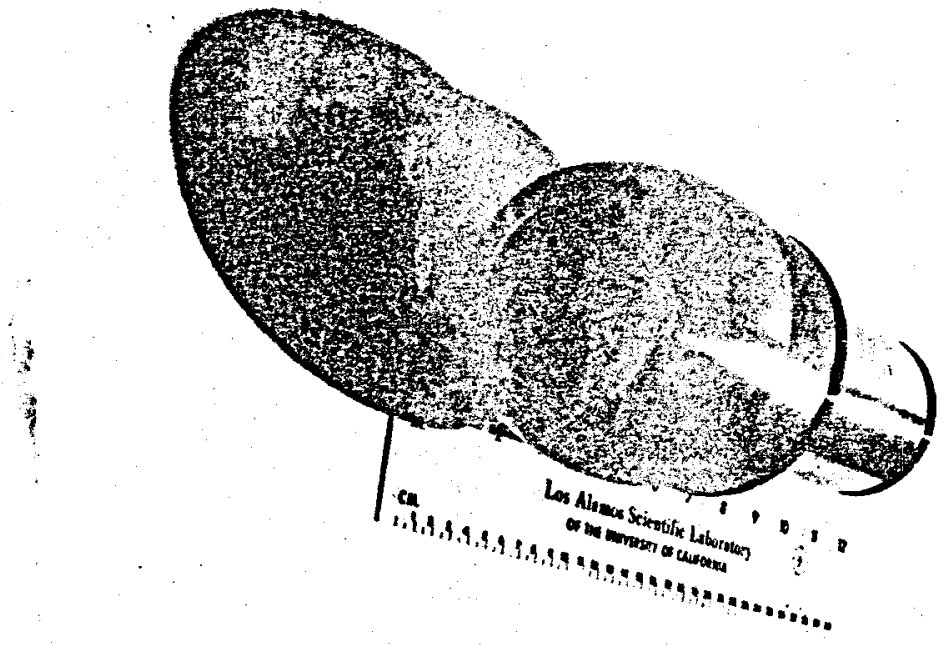

Fig. 11--Photograph of molybdenum penetrator body for coring-consolidating penetrator.

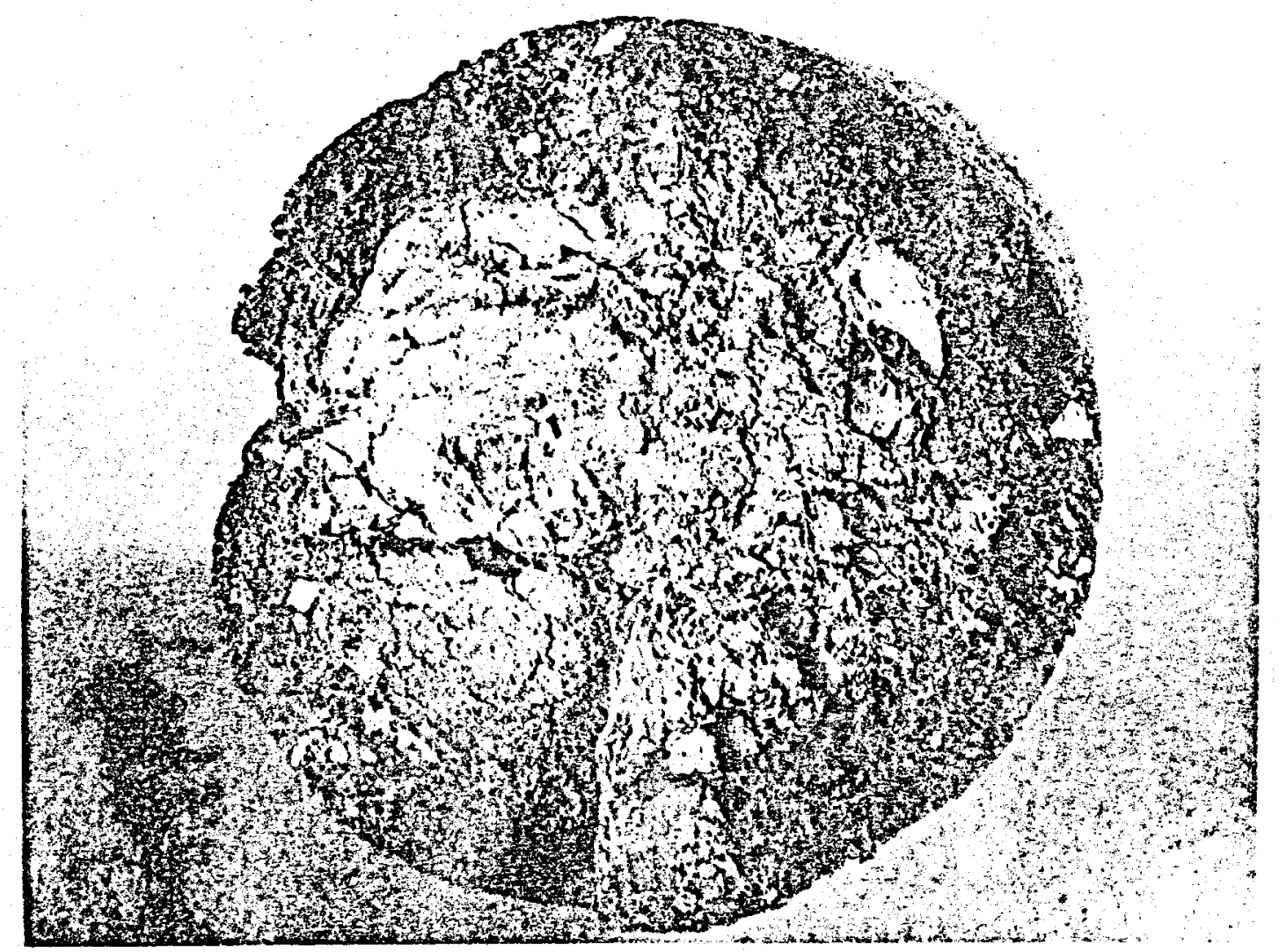

Fig. 12--Cross section of glass cased core removed from alluvium sample by coring-consolidating penetrator. 


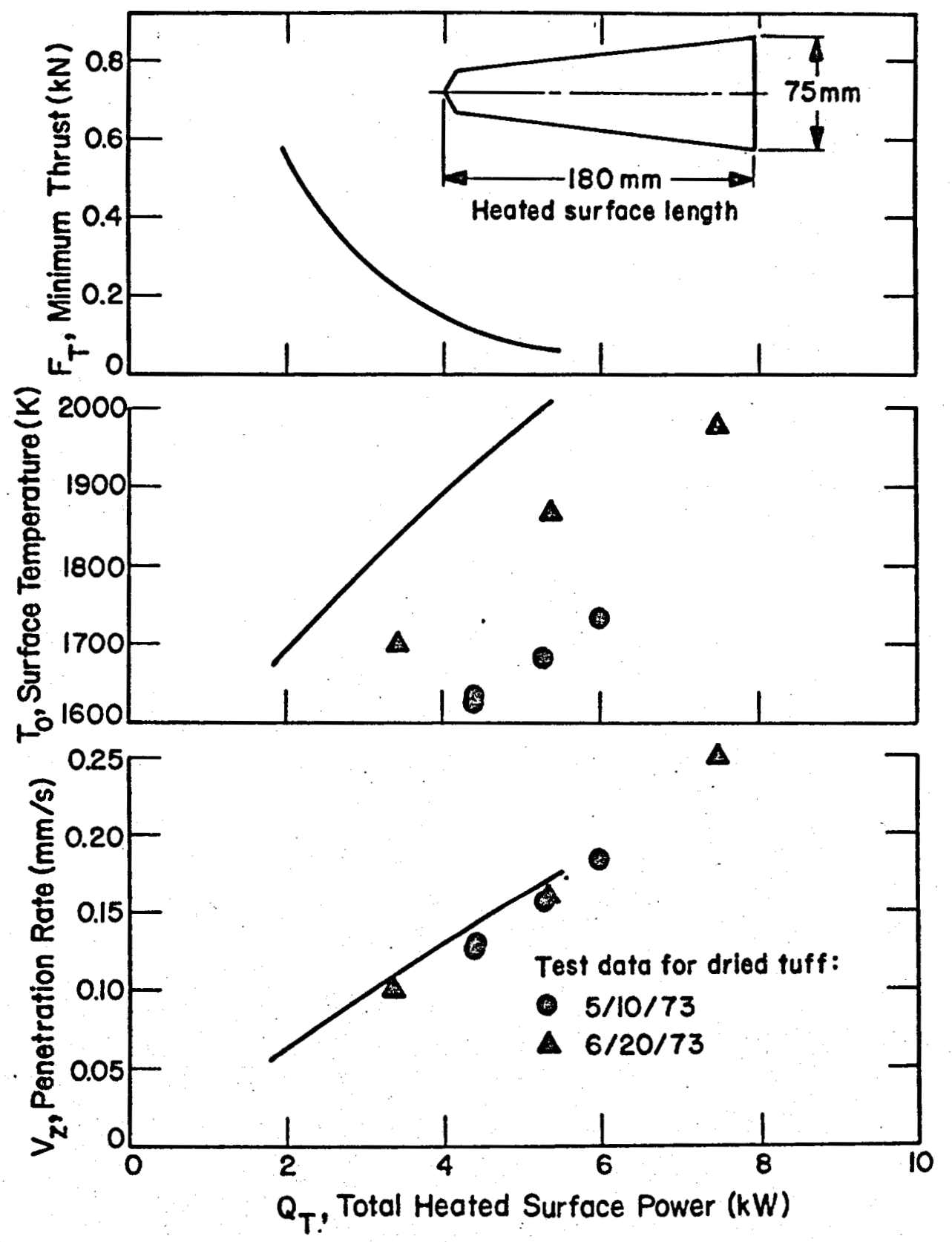

Fig. 13--Comparison of theoretical predictions for advance rate and surface temperature of $75 \mathrm{~mm}$. Consolidating penetrator with laboratory experimental data. 


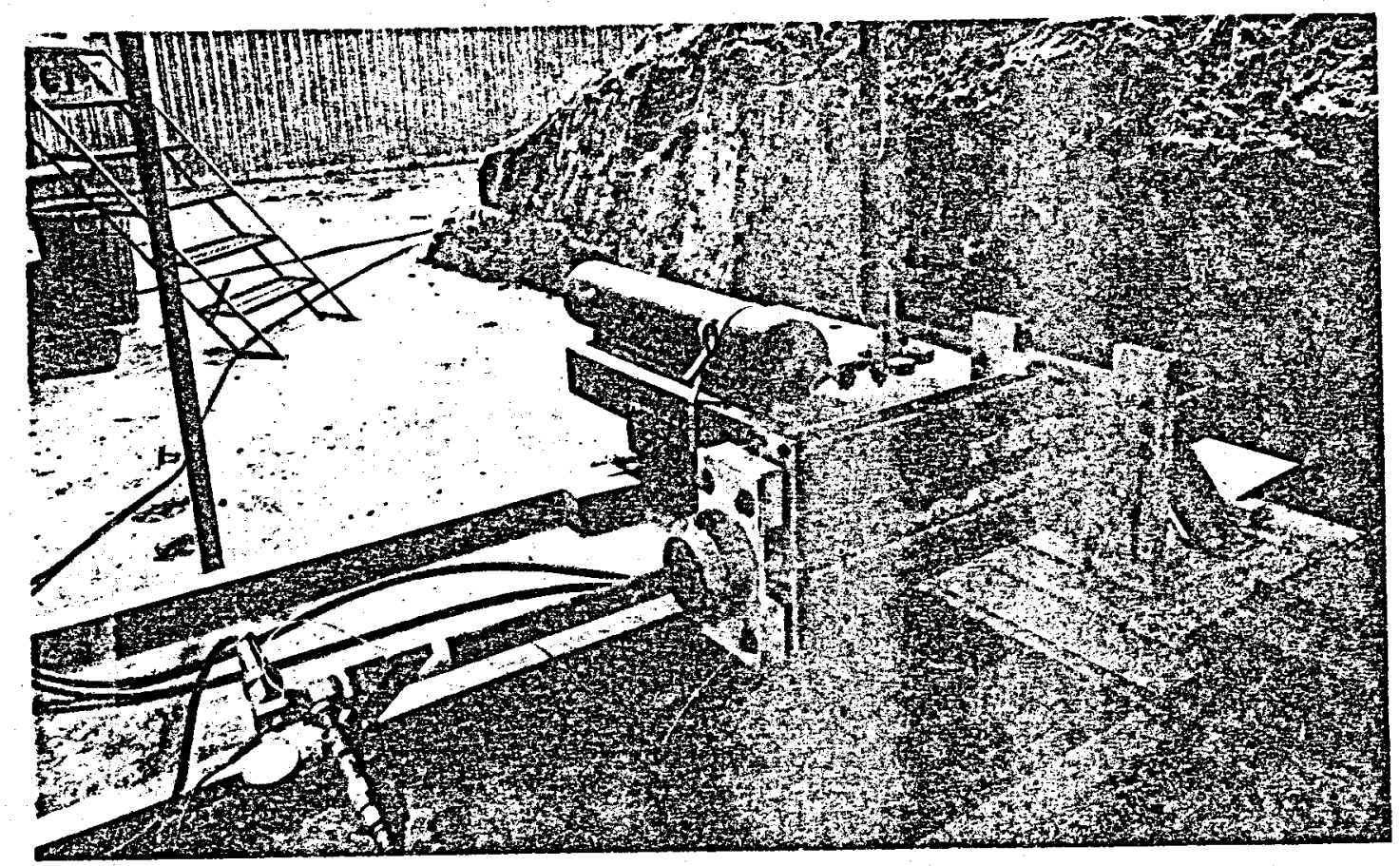

Fig. 14--Field test of a consolidating penetrator melting a horizontal hole into a tuff bank.

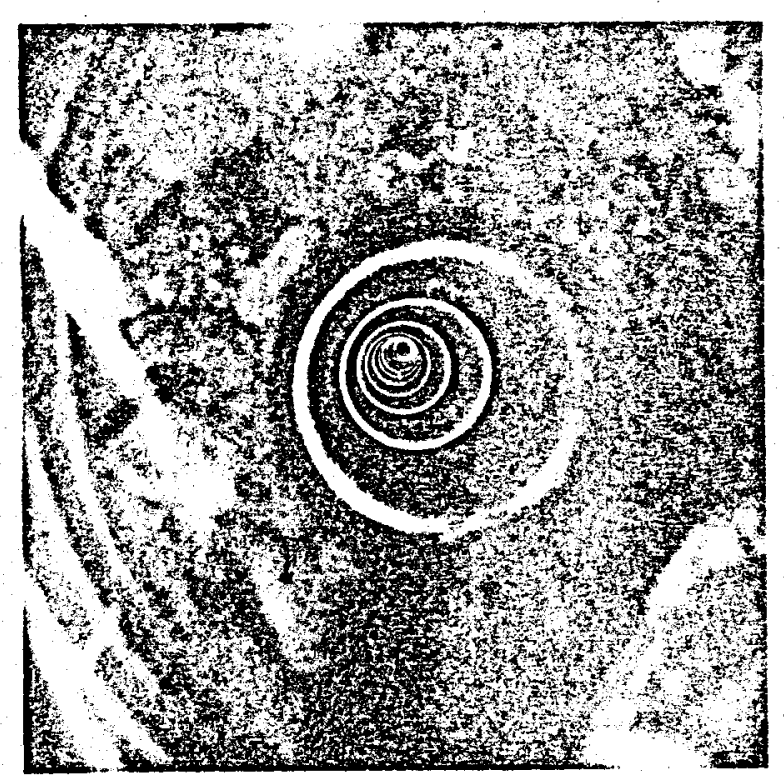

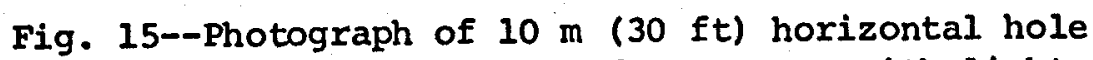
taken as a sequence of exposures with light source at different positions. Concentricity of light rings indicate straightness of hole. 




Fig. 16--Conceptual sketch of a mini-tunneling machine for geological surveys of tunnel routes. Note that unit is self propelled and returns a continuous core.

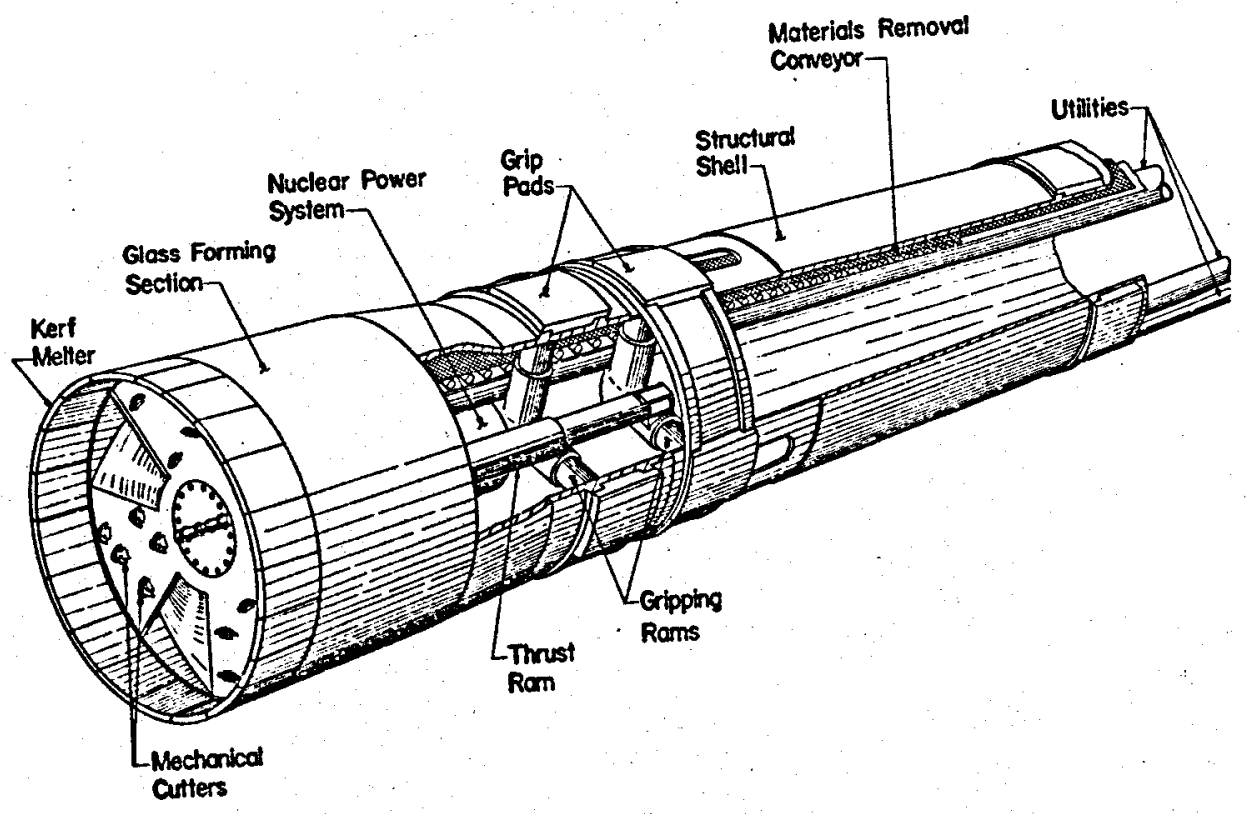

Fig. 17--Conceptual design of a large tunneling machine for soft, unstable ground. Peripheral kerf melter provides a glass lining for support while mechanical cutters remove material for tunnel face. 


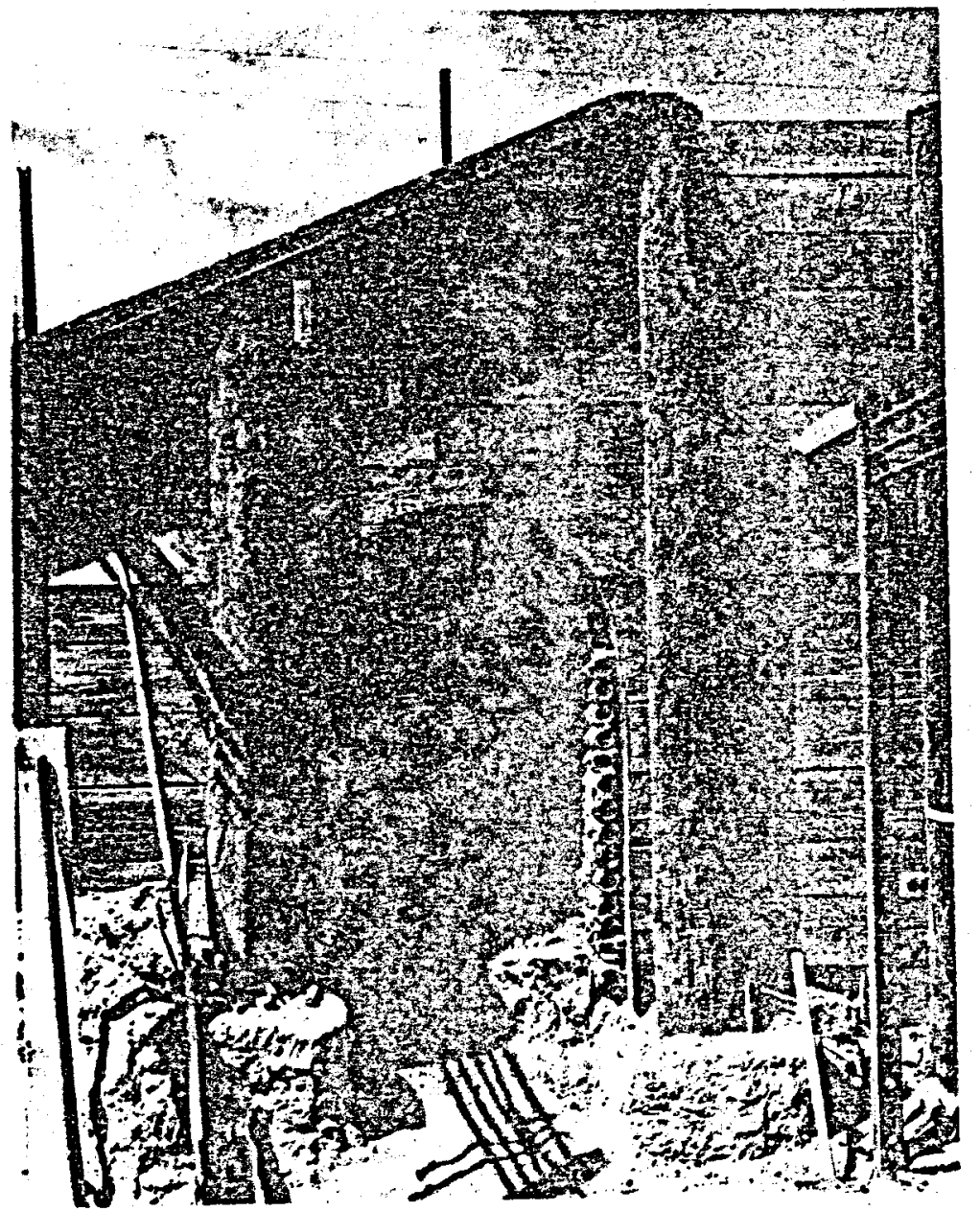

Fig. 18--Mock up of a formed-in-place glass tunnel periphery lining, melted sequentially with a $50 \mathrm{~mm}$ ( 2 inch) diameter consolidating penetrator into a loose gravel bank.

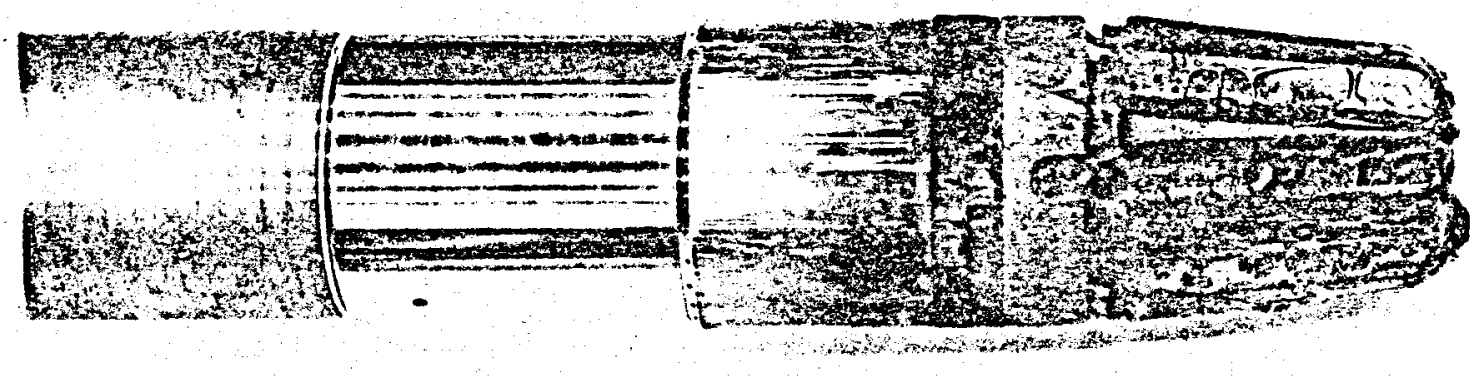

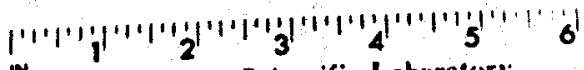

$$
\begin{aligned}
& \text { w. Los Alamos Scientific Laboratory }
\end{aligned}
$$

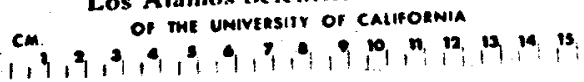

Fig. 19--Prototype geothermal penetrator for hot, hard rock. Note coating of basalt glass from testing. 


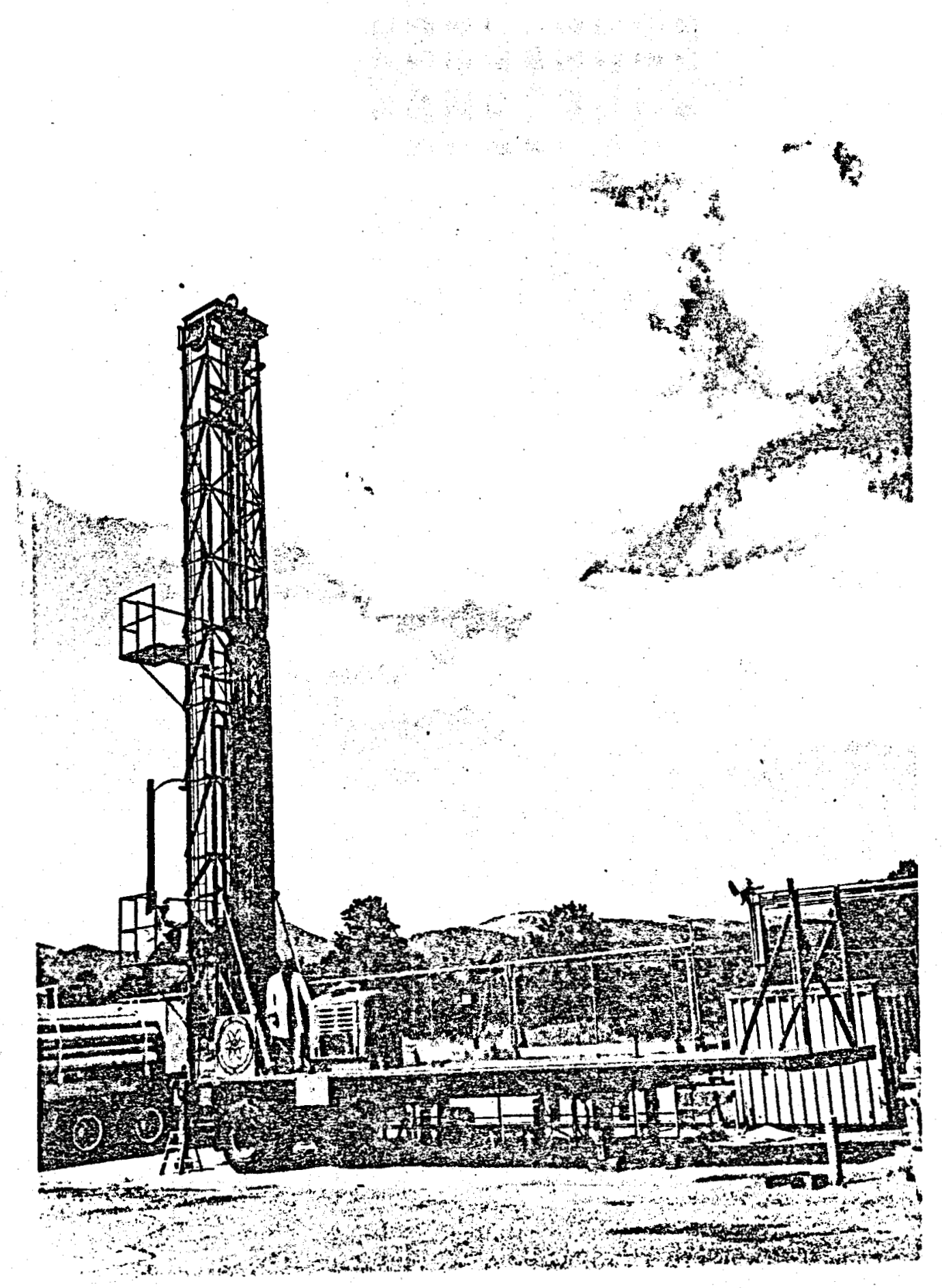

Fig. 20--Mobile drill rig for field trials of melting penetrators. Rig can handle up to $300 \mathrm{~m}$ (1000 ft) of $125 \mathrm{~mm}$ ( 5 inch) stem and has automatic hydraulic controls for programmed rate, thrust or position. 